\title{
PENGARUH LOKASI (PLACE), HARGA (PRICE), PELAKU WISATA (PEOPLE) TERHADAP MINAT BERKUNJUNG KEMBALI KE OBJEK WISATA PANTAIPASIR PUTIH PARBABA SAMOSIR
}

\author{
Elisa Friska Simarmata \\ Alumni Jurusan Manajemen Fakultas Ekonomi Universitas Negeri Medan \\ Nurul Wardani \\ Dosen Jurusan Manajemen Fakultas Ekonomi Universitas Negeri Medan
}

\begin{abstract}
This study aims to determine the influence of the place, price, people on the interest of visiting again at the tourist attraction of Pasir Putih Beach Parbaba Samosir. The population in this study as many as 17,182 tourists and using random sampling in sampling technique as much as 100 in the attractions of White Sands Beach Parbaba Samosir. Data collection technique in this research is done by spreading the questionnaire (questionnaire) which measurement with likert scale and processed statistically using multiple regression analysis and testing of $t$ test hypothesis, $f$ test, and coefficient of determination that previously data have been tested using validity test, test realibility, and the classical assumption test. Data processing using SPSS 22.0 for windows. From the results of validity test obtained rhitung $>$ rtabel for each question item and reliability test questionnaire obtained alpha cronbach each variable that is 0.786 for the variable X1, 0.779 for the variable X2, 0.667 for the variable X3 and 0.455 for variable $Y$. This value is greater from the significant level of rtabel is 0,306. Data analysis of each variable is obtained by multiple regression equation $Y=1,301+$ $0,042 X 1+0,049 X 2+0,136 X 3+e$. Obtained $R 2$ equal to 0,193, which means X1, X2 and $X 3$ explain influence to variable $Y$ equal to $19,3 \%$ while the rest explained variable outside tourist object. Partial test produced by each independent variable has an effect on dependent variable with the research significance is smaller than 0.1. The conclusion in this study is the location, price, actors of tourism positih influence on the interest of visiting again at the Object of White Sands Beach ParbabaSamosir
\end{abstract}

Keywords: Place, Price, People, Visitor Interest

\section{PENDAHULUAN}

Pariwisata di Indonesia sangatlah menarik dan beraneka ragam yang didukung oleh komponen keindahan alam dan kekayaan adat istiadat dari budaya setiap pulaunya.Disetiap pulau memiliki keunikan dan ciri khasnya masingmasing. Oleh karena itu Indonesia mempunyai potensi besar untuk menjadi kawasan wisata dunia. Salah satunya adalah Provinsi Sumatera Utara yang menawarkan berbagai macam objek wisata baik objek wisata Alam maupun wisata budayanya.

Pulau Samosir memiliki kekayaan alam dan budaya yang sangat menarik untuk dikembangkan menjadi objek wisata. Pulau Samosir yang berada lumayan jauh dari hiruk pikuk perkotaan menjadikan Pulau Samosir sebagai tujuan dari wisatawan untuk berkunjung. Kawasan di Pulau Samosir yang memiliki daya tarik wisata bahari 
yang sangat mengandakan potensi alam yang besar salah satunya adalah Pantai Pasir Putih Parbaba Samosir.

Masyarakat sekitar Pantai Pasir Putih Samosir menyediakan tempat istirahat, ruang ganti pakaian, tempat berbelanja pakaian serta souvenir bagi wisatawan-wisatawan yang datang dan juga makanan-makanan khas daerah Samosir bagi wisatawan yang ingin mencicipinya. Selain itu pada Pantai Pasir Putih Samosir banyak disediakan olahraga air seperti banana boat, bebek air, sampan dayung, boat, donat-donat bahkan odong-odong air. Pantai Pasir Putih Samosir juga menyediakan olahraga seperti bola volly dan terkadang masyarakat setempat mengadakan lomba volly dengan wisatawan untuk bersenangsenang.

Kelengkapan produk mempengaruhi kenyamanan dari wisatawan yang berkunjung ke Pantai Pasir Putih Samosir. Akan tetapi di Pantai PasirPutih Samosir tidak memiliki area parkir yang nyaman bagi wisatawan yang berkunjung. Apabila puncak liburan datang area parkir bagi wisatawan tidak memadai bahkan menimbulkan kemacetan sehingga mengganggu pengguna jalan sekitar Pantai Pasir Putih Samosir. Dan selain itu wisatawan beragama muslim memberi keluhan bahwa kurang disedikan restoran bahkan tempat yang menjamin halal untuk dimakan di sekitaran Pantai Pasir Putih Samosir.

Dengan banyaknya variasi serta kelengkapan produk yang ada di Pantai Pasir Putih Parbaba Samosir tentu akan berhubungan dengan harga dari produk wisata itu sendiri. Harga dari objek wisata Pantai Pasir Putih Samosir terbilang murah dimana dewasa dan remaja dikenakan biaya masuk sebesar Rp 2000,-/orangnya sedangkan anak-anak serta masyarakat setempat sama sekali tidak dikenakan biaya masuk. Keunikan dari Pantai Pasir Putih itu sendiri masih menganut budaya kekeluargaan dimana apabila masyarakat setempat yang mengunjungi Pantai Pasir Putih Parbaba tidak akan dikenakan biaya masuk.

Bisnis pariwisata tidak dapat berdiri tanpa pelayanan pelaku wisata yang diberikan kepada wisatawan. Pelayanan kepada wisatawan merupakan ujung tombak bagi pariwisata untuk mempertahankan objek wisata tersebut. Pelayanan dari pelaku wisata memiliki pengaruh besar bagi pariwisata untuk menambah wisatawannya atau malah menghilangkan wisatawan yang berkunjung. Sebagian pelaku wisata pada Pantai Pasir Putih Samosir merupakan warga sekitar yang bertempat tinggal disekitar lingkungan Pantai.

Warga sekitar Pantai Pasir Putih Samosir membuka usaha-usaha yang bertujuan saling menguntungkan dengan wisatawan. Pada Pantai Pasir Putih Samosir pelayanan dari pelaku usaha kepada wisatawan masih dikategorikan kurang maksimal karna beberapa warga sekitar terkadang belum menerapkan pelayanan yang ramah kepada setiap wisatawan yang berkunjung. Pelayanan yang ramah dalam arti tutur bahasa yang lembut dan pelayanan secara maksimal kepada wisatawan yang berkunjung ke Pantai Pasir Putih Parbaba Samosir.

Peluang besar yang dimiliki Pantai Pasir Putih Parbaba Samosir 
dari keindahan pantainya diharapkan mampu membawa banyak wisatawan untuk berkunjung. Pantai Pasir Putih Parbaba Samosir memiliki perairan dangkal, area bermain yang aman, dan juga batasan berenang bagi wisatawan yang berguna untuk keselamatan wisatawan. Lokasi, harga, dan pelaku wisataserta keunikan-keunikan yang ada pada Pantai diharapkan dapat menarik wisatawan untuk datang bahkan berminat untuk berkunjung kembali. Minat berkunjung kembali menurut umar (2008:76) adalah perilaku yang muncul sebagai respon terhadap objek yang menunjukkan keinginan pelanggan untuk melakukan kunjungan ulang.

Adanya masalah di Pantai Pasir Putih yang dilihat saat melakukan observasi ke Dinas Pariwisata Pulau Samosir dan berkunjung langsung ke Pantai Pasir Putih Parbaba, menjadi dasar masalah yang diangkat dalam penelitian untuk mencari penyebab dan solusi untuk masalah tersebut sehingga nantinya dapat bermanfaat untuk Pantai Pasir Putih Parbaba.

\section{KAJIAN PUSTAKA \\ Lokasi (Place)}

Menurut Kotler (2008:51)

"Salah satu kunci menuju sukses adalah lokasi, lokasi dimulai dengan memilih komunitas". Keputusan ini sangat bergantung pada potensi pertumbuhan ekonomis dan stabilitas, persaingan, iklim politik, dan sebagainya.

Lokasi menurut Lupiyoadi (2009:42), berhubungan dengan di mana perusahaan harus bermarkas dan melakukan operasi atau kegiatannya. Dalam hal ini ada tiga jenis interaksi yang mempengaruhi lokasi, yaitu:

1. Konsumen mendatangi pemberi jasa (perusahaan): apabila keadaannya seperti ini maka lokasi menjadi sangat penting. Perusahaan sebaiknya memilih tempat dekat dengan konsumen sehingga mudah dijangkau, dengan kata lain harus strategis.

2. Pemberi jasa mendatangi konsumen: dalam hal ini lokasi tidak terlalu penting, tetapi yang harus diperhatikan adalah penyampaian jasa harus tetap berkualitas.

3. Pemberi jasa dan konsumen tidak bertemu secara langsung: berarti penyedia jasa dan konsumen berinteraksi melalui sarana tertentu seperti telepon, komputer, atau surat. Dalam hal ini lokasi menjadi sangat tidak penting selama komunikasi antara kedua pihak terlaksana dengan baik.

Lupiyoadi

menyatakan lokasi berarti berhubungan dimana perusahaan harus bermarkas dan melakukan operasi. Dalam hal ini tiga jenis interaksi yang mempengaruhi lokasi, yaitu :

1. Konsumen mendatangi pemberi jasa

Apabila keadaan seperti ini maka lokasi menjadi sangat penting. Perusahaan sebaiknya memilih tempat dekat dengan konsumen sehingga mudah dijangkau, dengan kata lain harus strategis. 
2. Pemberi jasa mendatangi konsumen

Dalam hal ini tidak terlalu penting tetapi yang harus diperhatikan adalah penyampaian jasa tetap berkualitas.

3. Pemberi jasa dan konsumen tidak bertemu secara langsung

\section{Harga (Price)}

Menurut Kotler dan Amstrong (2010:314) yang dimaksud harga adalah "Sejumlah uang yang dibebankan atas suatu produk atau jasa atau jumlah dari nilai yang ditukar konsumen atas manfaatmanfaat karena memiliki atau menggunakan produk atau jasa tersebut". Harga yang ditawarkan kepada konsumen harus sesuai dengan pandangan konsumen atas nilai dan manfaat yang diperoleh dari produk tersebut. Harga juga memiliki peranan penting bagi perusahaan, karena harga mempunyai pengaruh terhadap kemampuan perusahaan dalam bersaing dengan perusahaan lain.

Menurut Philip Kolter (2008:345) "Harga adalah jumlah semua nilai yang diberikan oleh pelanggan untuk mendapatkan keuntungan dari memiliki atau menggunakan suatu produk atau jasa".

\section{Pelaku Wisata (People)}

Menurut Zeithaml dan Bitner (2013:322), orang adalah suatu kegiatan yang melibatkan orang, baik pihak konsumen maupun karyawan yang ada pada perusahaan untuk berpartisipasi selama proses transaksi atas jasa yang disediakan atau ditawarkan. Keterlibatan ini sebagai akibat dari karakteristik jasa yang tidak berwujud dan pelaksanaan produksinya yang bersamaan dengan mengkonsumsi oleh konsumen.

Menurut Lupiyoadi dan Hamdani (dalam Dhiba, Ich \& Maduwinarti : 2014) terdapat empat peranan atau pengaruh dari aspek orang yang mempengaruhi konsumen:

1. Contractors, orang disini berinterksi langsung dengan konsumen dalam frekuensi yang cukup sering dan sangat mempengaruhi keputusan konsumen untuk membeli.

2. Modifiers, orang disini tiak secara langsung mempengaruhi konsumen tetapi cukup sering berhubungan dengan konsumen, contoh :resepsionis

3. Influencers, orang disini mempengaruhi konsumen dalam keputusan untuk membeli tetapi tidak secara langsung kontak dengan konsumen.

4. Isolateds, orang disini tidak secara langsung ikut serta dalam bauran pemasaran dan juga tidak sering bertemu dengn konsumen. Contoh : karyawan bagian administrasi penjualan, SDM dan pemprosesan data.

\section{Minat Berkunjung Kembali}

Menurut soderlund dan ohman (dalam Hamjah: 2015) Minat/ intention merupakan pernyataan sikap mengenai bagaimana seorang akan berprilaku dimasa yang akan datang. Hicksv et Al (dalam Hamjah: 2015) 
Minat beli ulang/ repurchase intention merupakan suatu komitmen konsumen yang terbentuk setelah konsumen yang terbentuk setelah konsumen melakukan pembelian uatu produk atau jasa. Komitmen ini timbul karena kesan positif konsumen terhadap suatu merek dan konsumen merasa puas terhadap pembelian tersebut.

\section{METODE PENELITIAN}

Penelitian ini dilakukan di Objek Wisata Pasir Putih Samosir yang berlokasi di Parbaba berjarak 10 $\mathrm{km}$ dari Kota Pangururan. Apabila dari kota Medan berjarak sekitar \pm $195 \mathrm{~km}$. Populasi dalam penelitian ini adalah seluruh wisatawan yang berkunjung di Pantai Pasir Putih Parbaba Samosir

\section{HASIL PENELITIAN DAN PEMBAHASAN}

Dari hasil SPSS diatas dapat dijelaskan sebagai berikut :

$$
\begin{aligned}
& Y=1,301+0,042 X_{1}+0,049 X_{2}+ \\
& 0,136 X_{3}+e
\end{aligned}
$$

1. Konstanta sebesar 1,301 menyatakan bahwa jika tidak ada variabel $\mathrm{X}$, yaitu lokasi, harga dan pelaku wisata maka minat berkunjung kembali memiliki nilai sebesar1,301denganasumsi faktor lain konstan.

2. Koefisien X1 sebesar 0,042 menyatakan bahwa setiap terjadi peningkatan lokasi akan mempengaruhi minat berkunjung kembali sebesar 0,042 dengan asumsi faktor lain konstan.

3. Koefisien X2 sebesar 0,049 menyatakan bahwa setiap terjadi peningkatan hargaakan mempengaruhi minat berkunjung kembali sebesar 0,049 dengan asumsi faktor lain konstan.

4. Koefisien X3 sebesar 0,136 menyatakan bahwa setiap terjadi peningkatan pelaku wisata akan mempengaruhi minat berkunjung kembali sebesar 0,136 dengan asumsi faktor lain konstan.

Dapat diketahui bahwa nilai $\mathrm{F}=$ 7,640. Maka $F_{\text {hitung }}>F_{\text {tabel }}$ dan dengan tingkat signifikansi $0,000<0,1$. Maka dapat disimpulkan bahwa Lokasi, Harga, dan Pelaku Wisata sama sama berpengaruh terhadap Minat Berkunjung Kembali.

Hasil uji koefisien determinasi diketahui bahwa besarnya angka R2 adalah 0,193, yang berarti variabel lokasi, harga, dan pelaku wisata menjelaskan pengaruh terhadap variabel minat berkunjung kembali sebesar $19 \%$ sedangkan sisanya $81 \%$ dipengaruhi oleh variabel-variabel lain seperti promosi, pendapatan pengunjung, sistem operasi, atau variabel lainnya.

\section{PENUTUP}

Berdasarkan hasil penelitian dan pembahasan maka dapat ditarik kesimpulan sebagai berikut :

1. Lokasi berpengaruh terhadap minat berkunjung kembali di Pantai Pasir Putih Parbaba Samosir karena lokasi layak dikunjungi wisatawan.

2. Harga berpengaruh terhadap minat berkunjung kembali di Pantai Pasir Putih Parbaba Samosir karena harga sering sekali dikaitkan dengan kualitas sebuah produk wisata. Wisatawan akan menggunakan harga suatu produk sebagai standart kualitas produk sebelum dibeli. Harga mempengaruhi 
dalam menaikkan prestige dan memberikan kepuasan pribadi bagi konsumen.

3. Pelaku wisata berpengaruh terhadap minat berkunjung kembali di Pantai Pasir Putih Parbaba Samosir, sebab perlakuan pelaku wisata terhadap wisatawan menjadi tolak ukur gambaran bagaimana sikap yang ditunjukkan masyarakat lingkungan sekitar wisata terhadap wisatawan

4. Lokasi, harga, dan pelaku wisata mempengaruhi minat berkunjung kembali di Pantai Pasir Putih Parbaba Samosir

\section{DAFTAR PUSTAKA}

Dhiba, Diana Sarah, Ich \& Ayun Maduwinarti. 2014. "Analisis Pengaruh Bauran Pemasaran Jasa Terhadap Minat Pengunjung Pada Obyek Wisata Museum Kesehatan Dr. Adhyatma, MPH Surabaya". Jurnal Ilmu Ekonomi dan Manajemen. Vol. 1, No.1, 94-109

Hamjah Nurlaila \& Mukhlis Yunus, Syafruddin Chan, Jurnal Manajemen, Volume 4, No.2,Mei 2015 ISSN23020199

Kotler \& Keller. 2012. Marketing Management, 14th, Person Education. Jakarta: Erlangga 2008. Manajemen Pemasaran, Jilid 1, Jakarta, PT. Indeks Kelompok Gramedia. , dan Amstrong, Gary. 2010. Prinsip prinsip
Pemasaran Edisi 13, jilid 1. Jakarta : Erlangga , dan Kevin Lane Keller. 2009. Manajemen Pemasaran Jilid 1, Edisi 13, Terjemahan Bob Sabran, MM. Jakarta: PT Indeks , danSusanto. 2001. Dasardasar Pemasaran, Jilid 1, Edisi 9. Jakarta: PT. Indeks

Kuncoro, Mudrajat. 2009. Metode Riset untuk Bisnis dan Ekonomi. Jakarta: Erlangga

Lovelock Christopher. Et. Al. 2010.Pemasaran Jasa, Edisi 7, Jilid 2. Erlangga : Jakarta

Lupiyoadi, Rambat \& A. Hamdani. $2009 . \quad$ Manajemen Pemasaran Jasa, Edisi kedua, Jakarta, Salemba Empat.

Lupiyoadi, Rambat, 2013, Manajemen Pemasaran Jasa. Jakarta : PT Salemba Empat

Nugroho, Ryan \& Edwin Japarianto. 2013. " Pengaruh People, Physical Evidence, Produk, Promotion, Price, dan Place Terhadap Tingkat Kunjungan Di Kafe Coffe Cozies Surabaya". Jurnal Manajemen Pemasaran Petra. Vol. 1, No.2, 1-9

Osti, Linda. Disegna, Marta. \&Brida, Juan Gabriel. (2012). Repeat Visits and Intentions to Revisit a Sporting Event and Its Nearby Destinations. Journal of Vacation Marketing.

Rahman, Arif. 2010. Strategi Dahsyat Marketing Mix for Small Business Cara Jitu Merontokan Pesaing. 
JURNAL PLANS

Penelitian Ilmu Manajemen \& Bisnis

ISSN: $1978-7057$

E-ISSN: 2527-306X

Cetakan Pertama Jakarta : Trans Media Pustaka.

Sugiyono, 2012. Metode Penelitian

Bisnis. Cetakan ke-16, Penerbit: Alfabeta, Bandung

Sumarni, Murtidan John Soeprihanto. 2010. Pengantar Bisnis (Dasar-dasar Ekonomi Perusahaan). Edisike 5. Yogyakarta: Liberty Yogyakarta.

Swastha, Basudan T Hani Handoko, 2010.Manajemen

Pemasaran: Analisa dan Prilaku Konsumen. Yogyakarta: BPFE.
Tjiptono, Fandy, Gregorius, Chandra, 2009. Service, Quality, and Satisfaction. Penerbit Andi. Yogyakarta.

Undang Undang Dasar Republik Indonesia

Valarie A. Zethaml \& Marry Jo Bitner.2008.,Service Marketing. The McGraw Hill Companies, Inc

Zeithaml, Valarie A., Mary Jo Bither and Dwayne D. Gremler (2013).Services Marketing : Integrating Customer Focus Across the Firm, $6^{\text {th }}$ Edition. The McGraw-Hill Companies 